URSZULA BIJAK

Instytut Języka Polskiego PAN, Kraków

urszula.bijak@ijp.pan.pl

https://orcid.org/0000-0003-0378-6929
DOI: http://dx.doi.org/10.17651/ONOMAST.63.8

Onomastica LXIII, 2019

PL ISSN 0078-4648

\title{
POTAMONIMY ODANTROPONIMICZNE W DORZECZU WISŁY (PROBLEMY METODOLOGICZNE I TYPOLOGIA NAZW)
}

Słowa tematyczne: hydronomastyka, nazwy rzek, derywaty odantroponimiczne, chronologia, geografia nazewnicza

\section{UWAGI WSTĘPNE}

Nazwy wodne, stosując kryterium genetyczno-motywacyjne, można podzielić na dwie nadrzędne grupy: hydronimy odapelatywne i odproprialne. Wśród hydronimów pochodzących od nazw własnych, ze względu na typy onimów motywujących, wyróżnić można odtoponimiczne i odantroponimiczne (por. Bijak 2013, s. 21-23). Przedmiotem niniejszego artykułu są nazwy wód płynących pochodzące od antroponimów. Jest to część szerzej zakrojonych badań hydronomastycznych nad młodszą warstwą nazw wodnych - nad potamonimami odonimicznymi z obszaru dorzecza Wisły. Prezentowany materiał nazewniczy pochodzi z tomów serii „Hydronymia Europaea” (HE) i „Elektronicznego słownika hydronimów Polski” (ESHP), bazującego w znacznym stopniu na tej serii, opracowywanego w Instytucie Języka Polskiego PAN.

Nie powstała, jak dotąd, całościowa synteza hydronimii dorzecza Wisły, przeanalizowane zostały: potamonimy dorzecza Sanu (Rieger, 1969), dolnej Wisły (Rzetelska-Feleszko, Duma, 1977; Górnowicz, 1988), hydronimy dorzecza Bugu (Bilut, 1989), Wieprza (Mól, 1991), lewobrzeżnego Mazowsza (Duma, 1999), odapelatywne nazwy wód płynących (Bijak, 2013). Opracowania encyklopedyczne i monografie hydronomastyczne prezentują ogólne charakterystyki nazw wodnych Polski oraz ich różnorodne klasyfikacje poparte obszernym materiałem nazewniczym. W literaturze przedmiotu w odniesieniu do hydronimów odantroponimicznych pojawiają się generalizujące sformułowania. W „Encyklopedii kultury polskiej XX wieku” (t. 2), w rozdziale „Nazwy geograficzne” Ewa Rzetelska-Feleszko wymienia 6 baz leksykalnych, z których czerpano słownictwo służące tworzeniu nazw wodnych: wyrazy oznaczające cechy wody lub koryta rzeki, topografię okolicy, florę i faunę, toponimy i nazwy własne osób. Do 
grupy ostatniej zostały włączone podstawy odantroponimiczne: imiona, nazwiska, a także wyrazy pospolite oznaczające osoby. W odniesieniu do derywatów odantroponimicznych autorka stwierdza, iż ,ten rodzaj nazw wodnych jest rzadki” (Rzetelska-Feleszko, 1993, s. 416). W encyklopedii „Polskie nazwy własne” autor rozdziału „Nazwy wodne”, Kazimierz Rymut, omawiając nowszą warstwę hydronimów, konstatuje natomiast, że „Licznie w języku polskim występują nazwy wodne pochodne od nazw osobowych. Szczególnie często spotyka się je na terenach górskich i podgórskich" (Rymut, 1998, s. 275). W opracowaniu Zbigniewa Babika dotyczącego najstarszej warstwy nazewniczej na ziemiach polskich pojawia się stwierdzenie o „masie oczywistych derywatów dzierżawczych w hydronimii już w XII-XIII w." (Babik, 2001, s. 470), a w monografii Ewy Wolnicz-Pawłowskiej „O nazwach wodnych w Polsce” sformułowanie, iż wśród hydronimów bardzo często pojawiają nazwy utworzone od istniejących już nazw miejscowych lub nazw osobowych (Wolnicz-Pawłowska, 2013, s. 27).

Te zróżnicowane konstatacje o częstości występowania hydronimów odantroponimicznych wynikają z obserwacji i doświadczeń badawczych hydronomastów: E. Rzetelska-Feleszko zajmowała się głównie północną Polską, gdzie ten typ nazw pojawia się bardzo rzadko, K. Rymut południową, gdzie występuje często, E. Wolnicz-Pawłowska - środkową, gdzie nie jest rzadkością, natomiast Z. Babik najstarszymi hydronimami z obszaru całej Polski ${ }^{1}$.

Takie są stanowiska polskich hydronomastów, natomiast w opracowaniach hydronimii słowackiej przeważa przekonanie, że hydronimy, w podstawach których tkwią antroponimy, nie były motywowane bezpośrednio przez nazwy osobowe, lecz za pośrednictwem ojkonimów czy anojkonimów, z wyjątkiem nazw bardzo małych obiektów (por. Krško, 2006, s. 328-329, 336).

Celem mojego artykułu jest przedstawienie wstępnych ustaleń statystycznych dotyczących potamonimów odantroponimicznych ${ }^{2}$ w dorzeczu Wisły, ich chronologii, modeli nazewniczych, podstaw i rozmieszczenia geograficznego.

\section{PROBLEMY Z PORZĄDKOWANIEM MATERIAŁU NAZEWNICZEGO}

Badaniu toponimów często towarzyszą kłopoty w jednoznacznym ich zaklasyfikowaniu do odpowiednich typów derywacyjnych. Trudności takie pojawiają

1 W najstarszej warstwie hydronimów badacze często negują istnienie nazw odosobowych, czemu zdecydowanie sprzeciwia się Z. Babik, por. „Żałośnie wyglądają wypady przeciwko takim ustaleniom onomastyki słowiańskiej, jak przekonanie o istnieniu licznych odosobowych dzierżawczych nazw wodnych (i to nawet dość dużych obiektów) już u początków dokumentacji pisanej toponimii tych obszarów" (Babik, 2001, s. 31).

2 Część limnonimów odantroponimicznych została przedstawiona w artykule „Imiona w nazwach jezior i stawów w Polsce" (Bijak, Czopek, 2007). 
się także w wydzieleniu derywatów odantroponimicznych w potamonimii. Wynikają one z różnorodnych hipotez etymologicznych, z istnienia tzw. kontekstu onimicznego, czyli nazw miejscowych (ojkonimów) i nazw terenowych (anojkonimów) z tą samą podstawą dla obiektów zlokalizowanych w pobliżu i ustalenia stosunku pierwotności, a także $z$ faktu, że część antroponimów wywodzi się od podstaw apelatywnych związanych z florą i fauną, które również mogły się stać bezpośrednim tworzywem nazw wodnych.

\subsection{Nazwy o alternatywnych etymologiach}

Potamonimy etymologizowane jako odapelatywne staroeuropejskie lub słowiańskie posiadają alternatywne etymologie odantroponimiczne, np.

Jan(i)a, dziś Janka, rz., pd. Wierzycy, o dług. ponad $30 \mathrm{~km}$ (woj. pomorskie): in Janam (1274), Jonka (1882), Janka (1961); por. też n. m. Jania (dziś Stara Jania): in Jene (1290), de Jana (1305), Janya (1534) NMPol IV 53, wtórną w stosunku do nazwy rzeki. Hydronim traktowany był z reguły jako staroeuropejski, pochodzący od ide. *iā- 'jechać' (Rzetelska-Feleszko, Duma, 1977, s. 44; Udolph, 1990, s. 126-8) lub ide. *jānā 'potok' (HE I 9), natomiast Z. Babik wiąże nazwę rzeki z chrześcijańskim im. Jan i uznaje za niekwestionowany derywat odantroponimiczny, por. „w toponimii polskiej nie ma nazw miejscowych i wodnych na Jan-, których nie dałoby się powiązać słowotwórczo z tym imieniem" (Babik, 2001, s. 402-3).

Liwocz, pot., dziś nieistniejący, w dorzeczu Wisłoki (woj. podkarpackie): $L i$ wocz (1360); por. też n. góry Liwocz (1475). Za pierwotny w gnieździe uważany jest z reguły hydronim i łączony z pierwiastkiem ide. *ley- 'kapać' (Udolph, 1990, s. 141-5), także ze słowiańskim gw. liwy, ukr. liwyj 'lewy’ (Lubaś, 1963, s. 209, 221; HE XV 76). Z. Babik zaś wiąże nazwę z rzadką n. os. Liwot (Snazw rejestruje 5 nosicieli o tym nazwisku), z suf. *-jb, a wygłosowe $c z$ objaśnia jako hiperyzm wobec mazurzenia. Odnotowuje też równobrzmiącą nazwę pasma górskiego oraz szczytu znanego już w średniowieczu i odosobowy oronim właśnie, skłonny jest uznać za pierwotny (Babik, 2001, s. 428-9)³.

Osola, rz., zapewne średniowieczne miano współczesnej Strzegomki (woj. świętokrzyskie): in fluvio Ossolya (1470-80), por. też n. m. Oszalya, Ossolya (1470-80) NMPol VIII 159, dziś Ossala. Nazwę wodną J. Udolph podejrzewa także o pochodzenie staroeuropejskie od pierwiastka *as- 'suchy' z formantem *-olya $(1990$, s. 232-3, 319), inni autorzy opowiadają się za genezą odantroponimiczną od rodzimej n. os. *Osola lub *Osoła (HE XVI 102;

3 Onomaści słowaccy w nazwie Livina widzą podstawę słowiańską *liv- o znaczeniu 'rozlewająca się woda przy ujściu' i rekonstruują czas. *livati, por. Hladký, 2004, s. 124. 
Babik, 2001, s. 494). Nazwa wodna i miejscowa zostały odnotowane w tym samym czasie i trudno rozstrzygnąć, która z nich była pierwotna. W NMPol hydronim nie jest wzmiankowany, a ojkonim objaśniany jako odantroponimiczny.

Gdola, dziś Gdolanka, str., w dorzeczu Bugu, o dług. ponad 18 km (woj. lubelskie): Gdolya (1432), por. też n. m. Gdola 1796 NMPol III 111-2. Hydronim był traktowany jako odapelatywny od psł. podstawy * $g b d$ - o charakterze topograficznym (HE X 46), ale ta koncepcja nie jest ostatnio zbyt popularna. W okresie staropolskim notowana jest n. os. Gda, więc możliwy jest derywat *Gdola (por. nazw. Gdela, Gdala Snazw). Z. Babik wszystkie toponimy z $G d$ - uważa za odosobowe, a nazwę wodną traktuje w tym gnieździe jako pierwotną (Babik, 2001, s. 384-5).

Myśla, rz., ld. Bugu, o dług. 22 km (woj. mazowieckie): Myśla (1909). Wcześniej w XIII w. notowany jest równobrzmiący hydronim w dorzeczu Odry. E. Bilut (HE X 111) opowiada się za słowiańską genezą nazwy od czas. *my-ti 'myć', z suf. -śla, natomiast J. Udolph (1990, s. 168-169) uważa ją za straroeuropejską, od pierwiastka *mūs- 'mech'. Z. Babik (2001, s. 468), za A. Bańkowskim, widzi tu derywat odantroponimiczny od n. os. Myśl (: Myślibor), z sufiksem *-ja, choć niepokoi go brak równobrzmiącego ojkonimu.

Wymienione powyżej nazwy budzą jednak spore wątpliwości, jeśli chodzi o pochodzenie odantroponimiczne.

\subsection{Gniazda nazewnicze $\mathrm{z}$ toponimami}

o trudnym do ustalenia stosunku pierwotności

W przywoływanych przykładach pojawiały się już równobrzmiące hydronimy i ojkonimy, które uznawane były za wtórne. O przyporządkowaniu hydronimu do grupy derywatów odantroponimicznych decyduje głównie chronologia zapisów; jeśli hydronim notowany jest wcześniej niż inny równobrzmiący toponim, to traktowany jest jako pierwotny w tym gnieździe onimicznym. Ale często pojawiają się one właściwie w tym samym czasie, np. Klimaszewnica, str., o dług. $14 \mathrm{~km}, \mathrm{w}$ dorzeczu Biebrzy (woj. podlaskie): super rivulo Climaschewnicza (1414-25)1457, por. też n. wsi Klimaschevicza (1422) NMPol IV 497, oraz n. jez. cum lacu Climaschewnycza (1471) (ESHP). Nazwy związane są z n. os. Klimasz (: Klemens), możliwe że łączyć je trzeba z kupcem drzewnym Klemensem z Goniądza, który działał w tych stronach na początku XV w. Za pierwotną uznaję w tym gnieździe nazwę rzeki, podobnie sądzą historycy (por. Wiśniewski, 1975, s. 41). W średniowieczu rzeki odgrywały dość istotną rolę, były punktami orientacyjnymi, wyznaczały granice i to one wcześniej przed tworzonymi osadami mogły być i były poddawane nominacji. Hydronim jednak ma strukturę 
typową dla derywatów od nazw na -ewo. Nie można więc wykluczyć, że istniał pierwotnie ojkonim * Klimaszewo.

Jeszcze trudniejsza jest sytuacja na terenach podgórskich, gdzie dość często występują gniazda onimiczne oparte na tym samym antroponimie. Jeśli równobrzmiące nazwy obiektu wodnego i lądowego pojawiają się w tym samym czasie, za pierwotny w takim gnieździe uznaję ojkonim lub anojkonim, nie hydronim, np. Adamkówka, pot., o dług. 1,6 km, w dorzeczu Skawy (woj. małopolskie): Adamkówka (1964), por. też n. m. Adamkówka (1963); ta od im. lub nazw. Adamek, z suf. -ówka (HE XII 9). Na tym obszarze mamy do czynienia z toponimami należącymi do młodszej warstwy nazewniczej i z niewielkimi obiektami. Hierarchia w przestrzeni (także onimicznej) uległa zmianie, istotniejsze stały się obiekty zamieszkane i ich nazwy.

Jeśli natomiast nazwy obiektów powiązanych lokalizacyjnie różnią się formą, a powstały w tym samym czasie, dopuścić można równoległe akty kreacji od antroponimów, np. Goryczkowy Potok, pot., o dług. 3 km, w dorzeczu Dunajca (woj. małopolskie): Gorickow Bach (1846), Goryczkowa a. Goryczkowy Potok (1965); por. n. hali (polany) Hala Gorickowa (1846), od nazw. Goryczka notowanego już od XVII w. w okolicach Zakopanego (Bubak, 1970, s. 123); por. też n. doliny Goryczkowej (1880), n. góry Czuba Goryczkowa (1962), n. źródła Goryczkowe Wywierzysko i inne (HE XIII 72, 433).

\subsection{Odantroponimiczne ogniwa pośrednie}

Często podstawami hydronimów stawały się odantroponimiczne nazwy młynów położonych nad rzekami, np. Ryszka, rz., o dług. $20 \mathrm{~km}$, w dorzeczu Wdy (woj. kujawsko-pomorskie): Rischker Fl. (1796-1802), Ryszka al. Ryszkowska Struga, niem. Rischkefließ ... wypływa przy młynie Ryszce z jeziora (1889); por. Młyn Ryszka. Paweł Ryszka młynarz (1664), Ryszka, niem. Rischke, os. młyn. nad strugą Ryszka (1889) (HE I 28). W wypadku rz. Ryszki mamy udokumentowaną wcześniej nazwę młyna. Hydronim nie pochodzi bezpośrednio od antroponimu, jest ponowiony z nazwy młyna, należy go więc z badanej grupy nazw wyłączyć.

Można przypuszczać, iż w badanym materiale jest wiele hydronimów odantroponimicznych, w których to pośrednie ogniwo - nazwa młyna, nazwa terenowa, nazwa przysiółka - nie zostały udokumentowane lub odnalezione w dostępnych źródłach, dotyczy to zwłaszcza hydronimów równych formalnie antroponimom, np. Ciemięga, Kur, Waglec (por. Duma, 1999, s. 61-2), także pluralnych Dziebaki, Fiuki, Sarniki.

Po przeprowadzeniu szczegółowych analiz do grupy derywatów odantroponimicznych zaklasyfikowano nieco ponad 900 potamonimów, nie zawsze bez pewnych wątpliwości. 


\section{CHRONOLOGIA ODANTROPONIMICZNYCH NAZW RZEK}

Potamonimy z antroponimicznymi podstawami motywacyjnymi pojawiają się w źródłach od XIII w. - Lubchor(z)a, Radomierza, Witowy Dziat i Wtostowa (4), w XIV wieku udokumentowane są: Bobowa, Chomik/Chomikowy, Czepina, Kozłówka, Liwocz, Michałowa Rzeka, Niemila, Szczachów Potok, Wadziszowa, Więciechów (12), spory przyrost odnotować można w wieku XV — ponad 40, w XVI — również ponad 40, w XVII zapisano po raz pierwszy tylko 10 nazw (ale liczba ta wynika głównie $\mathrm{z}$ faktu, że dla tego wieku dysponujemy niewielką liczbą źródeł), w XVIII w. przybywa ponad 100 hydronimów, w wieku XIX ponad 200, w XX ok. 500. Ta obfitość zapisów ujawniająca się w 2 ostatnich stuleciach świadczy głównie o słabości bazy materiałowej oraz o ograniczonej w okresach wcześniejszych archiwizacji nazw małych cieków, bo z takimi obiektami mamy tu głównie do czynienia. Jest to chronologia pojawiania się nazw wodnych w dokumentach, ich czas powstania mógł być, i zapewne był, nieco wcześniejszy.

Potamonimy odantroponimiczne identyfikują głównie małe cieki o długości poniżej $10 \mathrm{~km}$, często też dziś nieistniejące, ale w XIII w. pojawia się nazwa $R a$ domierza (dziś Radomka) ${ }^{4}$, Lubchora (dziś Lubienka, w dorzeczu Zgłowiączki) dla obiektu o długości ponad $40 \mathrm{~km}$, później Rzepechowa Rzeka (identyfikowana z Drwinką), Lubrzanka ${ }^{5}$ (w dorzeczu Nidy), Jania (dziś Janka, w dorzeczu Wierzycy) o długości powyżej $30 \mathrm{~km}$, Pietraszka (w dorzeczu Biebrzy), Gilów$k a$ (w dorzeczu Sanu), Żebrówka (w dorzeczu Pilicy), Grabar i Myśla (w dorzeczu Bugu) o długości powyżej $20 \mathrm{~km}$.

\section{MODELE NAZEWNICZE}

Odantroponimiczne nazwy rzek tworzone są: przez transonimizację nazw osobowych (9\%), z wykorzystaniem derywacji fleksyjnej (3,5\%), przy użyciu różnorodnych sufiksów przymiotnikowych: -ow- $(22,5 \%)$, -sk- (z rozszerzeniem $9 \%)$, -in- (2\%), sporadycznie *-j- (1\%), -n- (ok. 1\%) i rzeczownikowych głównie - $k a$ (z rozszerzeniami, 19\%), także -ec ( $2 \%$ ), rzadko -ica, -izna, -icha, -ocha, $-i k$, -ek (pojedyncze nazwy stanowiące łącznie ok. 2\%) oraz kompozycji (29\% stanowią zestawienia, odnotowano też kilka zrostów i wyrażeń przyimkowych).

Wśród modeli nazewniczych najliczniej reprezentowane są $\mathrm{w}$ badanym materiale nazwy zestawione z jednym członem odantroponimicznym a drugim oda-

4 Radomierza (Radomka) ma ponad 100 km długości, ale według Z. Babika n. Radomierza odnosiła się pierwotnie do Mlecznej (płynącej przez Radom, ta ma prawie $30 \mathrm{~km}$ ), a dopiero później przeniesiona została na Radomkę (2001, s. 527).

5 Ta jednak niepewna jako odosobowa. 
pelatywnym, oznaczającym typ obiektu, najczęściej jest to potok (193 nazwy), potoczek, rzeka, rzeczka, struga, rów, stok ${ }^{6}$ itp. Pierwsze takie zestawienia pojawiają się już w XIII w. - Witowy Dziat, pot. w dorzeczu Raby, dziś nieistniejący, i XIV—Michałowa Rzeka (w dorzeczu Czarnej), Szczachów Potok (w dorzeczu Dunajca). W kolejnych stuleciach przybywa po kilka, kilkanaście takich nazw, a w XX w. prawie 200. Człony odantroponimiczne przybierają najczęściej formy przymiotników z suf. -ów/-owy (160) ${ }^{7}$, np. Bartów Potok, Potok Burchatów, Dziedziców Strumyk, Gutów Potok, Kuchów Potok, Nafrów Potok, Paczottów Potok, Szymanów Stok, Walów Potok; Boruszowy Potok, Chrycowy Potok, Grzesiczkowy Potok, Kossowy Rów, Kurowy Potok, Potok Macherowy, Piatkowy Stok, Warcholowy Potok, Potok Wilcentowy, Zdunkowy Rów; z suf. -owa (7), np. Kuraszowa Rzeczka, Piłatowa Rzeczka, Szubzdowa Zawonia'; z suf. -sk(wraz z rozszerzeniami 62), np. Marciszowski Potok, Potok Frankowski, Mierkowski Potok, Okrzesiński Potok, Polczowski Kat, Urbanowski Potok.

Sufiksy te równie często są używane w formacjach jednoczłonowych, najwyższą frekwencję ma suf. -ów/-owy (188), np. Bobków, Hostyszów, Łukaczów, Miłoszów, Więciechów; Chomikowy, Ciporowy, Czapielowy, Gawłowy; -owa (18), np. Bobowa, Szyszkowa, Wadziszowa; -ski (z rozszerzeniami, 50), np. Biegoński, Blejarowski, Czemerowski, Drobkowski, Krupiński, Lukaszkowski, Madoński, Michajłowski, Pawlinkowski; -ska (z rozszerzeniami, 11), np. Gilowska, Perzowska. Bardzo produktywny jest w nazwach rzeczownikowych suf. -ka (wraz z rozszerzeniami -ówka, -anka, 174), np. Bakinówka, Denowka, Dzirzówka, Gawtówka, Guniuszka, Kmitówka, Kozłówka, Ludwigówka, Mastówka, Piwowarczykówka, Wakulanka, Węgierka; dużo niższą frekwencję ma suf. -ec, np. Bartoszowiec, Gałowiec, Jaskowiec, Kaniowiec, Lenarciec, Ratulowiec, Wikowiec.

Na uwagę zasługują jeszcze hydronimy utworzone od antroponimów bez wykładników formalnych, które tworzą sporą grupę i spotykane są od XV w., np. wspomniane wcześniej Gdola, Osola (dyskusyjne co do antroponimiczności podstaw), Bandura, Kurman, Lipiec, Luraniec, Piprek, Ractaw, Radoń.

Na obszarach pogranicza (głównie dorzecze Sanu) spotkać można także nazwy z sufiksami o wschodniosłowiańskiej postaci fonetycznej, np. łemk. Koditka (pol. -ówka), Broditski Potok, Krehlitski Potok, Kryszkitski Potok (pol. -owski).

6 Ten człon jest charakterystyczny dla hydronimów mazowieckich.

7 Przytaczam jedynie wybrane nazwy o najstarszych poświadczeniach.

8 Człon Zawonia łączony był błędnie z czasownikiem zawoniać 'zawonieć, zapachnieć' (HE XIX 189, Bijak, 2014, s. 110). Wywodzić go należy od apelatywu topograficznego (znanego z gwar ruskich Białostocczyzny) zawonia 'zatoka rzeczna, zalew, wąskie wijące się rzeczki, głębia wodna' (Lapicz, 1981, s. 69). 


\section{CHARAKTERYSTYKA PODSTAW ANTROPONIMICZNYCH}

Odantroponimiczne nazwy rzek tworzone były głównie od odapelatywnych nazw osobowych (ok. 54\%), np. Bandura, Baranów Potok, Bąk, Dudowiec, Gilówka, Grajcarek, Habdów Potok, Kaniowiec, Kluska, Kuligów Potok, Lipiec, Matczyn, Mastówka, Rydzoniówka, Świerszcz, Trzaska, Watęga, Wilkowina lub od apelatywów osobowych, np. Dziedziców Strumyk, Garnczarka, Hawiarski Potok (por. gw. ap. hawiarz 'górnik', nazw. Hawiar, RymSEN I 299), Kanat Partyzantów, Lepacka Struga (por. ap. lepak 'murarz', nazw. Lepak, RymSEN II 16), Pastorów Potok, Piwowarczykówka, Plebanka, Popadianki Rów, Popówka, Sierotka, Zdunkowy Rów. Reprezentowane są także odapelatywne antroponimy o wschodniosłowiańskiej proweniencji, np. Hadyszów (por. n. os. Hadysz od ukr. had 'wąż'), Husaków (por. n. os. Hus(z)ak od ukr. ap. husak 'gąsior') (HE XVII 95).

Często podstawami stawały się nazwy osobowe pochodzące od imion chrześcijańskich (ok. 23\%), np. Abrahamów/Abramowy Potok, Aduchów, Bernatka, Eliaszówka, Elżanówka, Gawłowy, Gowinka, Jurczycha, Lodwigówka, Luraniec, Łucjanówka, Madejowy Potok, Makarowski, Marciszewski, Michałowa Rzeka, Mikosz, Oleksów Potok, Pietraszka, Potok Frankowski, Rachwatówka, Szymanów Stok, Wawaków, także żeńskich, np. Halszka, Erwina, Irenka, Maryna, Marynin Potok, Sonia. W dorzeczu Sanu również odnotować można podstawy o cechach ukraińskich, np. Chomów (por. ukr. Choma od Tomasz), Ilków (por. ukr. n. os. Il'ko, łemk. Ilko od Ilija, a to od Eliasz, HE XVII 48, 96).

Rzadziej wykorzystywane były antroponimy powstałe od rodzimych imion skróconych (ok. 20\%), np. Goszcza, Radoń, Stanka, Sulów Stok, Więckowica. Sporadycznie jako tworzywo nazw rzecznych używane były imiona dwuczłonowe (ok. 1\%), np. Bogdan, Gościeradowiec, Jarosławka, Lubgoszcza, Racław, Radomierza.

Podobny jest udział nazw etnicznych (ok. 3\%), np. Cygan, Lachowiec, Madziarów, Rusnaków Potok, Uherka, Żydowski Rów i nazwisk pochodzenia obcego, głównie niemieckiego (ok. 3\%), np. Barenta, Burkot, Goczałka, Gunczmanów Potok, Harszówka.

Hydronimy motywowane były również nazwiskami na $-s k i$, stanowią one ok. 2\% analizowanego zbioru, np. Bielawskiego Bród, Gawlowski, Grajewszczyzna, Potok Czajkowskiego.

Wśród podstaw odantroponimicznych mamy więc pełne spektrum typów nazw osobowych. 


\section{GEOGRAFIA POTAMONIMÓW ODANTROPONIMICZNYCH}

Rozmieszczenie potamonimów jest nierównomierne, ale też sieć hydrograficzna jest asymetryczna (73\% powierzchni dorzecza przypada na dopływy prawobrzeżne). W badanym zbiorze odantroponimicznych nazw wód płynących $76 \%$ odnosi się do cieków prawobrzeżnych górnej Wisły aż po dorzecze Sanu, pozostałe $24 \%$ stanowią cieki lewobrzeżne i prawobrzeżne powyżej Sanu. Udział procentowy nazw wodnych $\mathrm{z}$ antroponimem $\mathrm{w}$ podstawie $\mathrm{w}$ poszczególnych dorzeczach przedstawia się następująco:

— dorzecze górnej Wisły od źródeł do Soły i Przemszy, głównie dorzecze Soły (HE IX) $-10 \%$;

— prawobrzeżne dopływy Wisły między Sołą a Dunajcem (HE XII) - 19\%, w tym dorzecze Skawy $10 \%$, a Raby prawie $9 \%$;

— dorzecze Dunajca (HE XIII) - 25,7\%;

- prawobrzeżne dopływy Wisły między Dunajcem a Wisłokiem (HE XV), głównie dorzecze Wisłoki - 5\%;

- dorzecze Wisłoka (HE III) - 5\%;

- dorzecze Sanu (HE XVII i XVIII) - 11\%;

- lewobrzeżne dopływy Wisły od Przemszy do Pilicy (HE XVI) - prawie 5\%;

- dorzecze Wieprza (HE VI) - 1,7\%;

— lewobrzeżne dopływy Wisły od Pilicy po ujście Brdy (HE XIV) - 2\%;

- dorzecze Bugu (HE X) - 5\%;

— dorzecze Narwi (HE XIX do Biebrzy oraz poniżej) - 7,6\%;

— dolna Wisła (HE I) - 3\%.

\section{ZAKOŃCZENIE}

Potamonimy odantroponimiczne stanowią ok. 6,8\% nazw wód płynących dorzecza Wisły, szacowanych ogółem na ponad 13,5 tys. Nie tworzą więc znaczącej grupy w porównaniu z nazwami odapelatywnymi czy odtoponimicznymi.

Analiza zapisów źródłowych wykazała, że pojawiają się one w dokumentach sporadycznie już w XIII w., do wieku XVI ujawnia się jedynie 12\% tego typu nazw, większość notowana jest dopiero w XIX i XX wieku. Taki rozkład statystyczny jest dość typowy dla nazw wód płynących dorzecza Wisły — znaczny przyrost potamonimów odapelatywnych odnotować można również w XIX i XX w. (por. Bijak, 2013, s. 204).

Potamonimy odantroponimiczne reprezentują różnorodne modele nazewnicze, ale najczęściej występują jako człony zestawień utworzone za pomocą suf. -ów/-owy, formacje jednoczłonowe z tym samym sufiksem oraz derywaty z suf. $-k a$. Identyfikują głównie obiekty położone między Sołą a Dunajcem, zwłasz- 
cza w dorzeczu Dunajca, a więc na terenach górskich i podgórskich, tak jak to stwierdził K. Rymut.

Jako podstawy tych potamonimów występują przeważnie nazwy osobowe odapelatywne i od imion chrześcijańskich, rzadko pojawiają się antroponimy od imion dwuczłonowych czy skróconych oraz etnonimy.

Tak wstępnie zarysowana problematyka hydronimów od nazw osobowych będzie przedmiotem dalszych badań.

\section{LITERATURA}

Babik, Z. (2001). Najstarsza warstwa nazewnicza na ziemiach polskich (w granicach wczesnośredniowiecznej Słowiańszczyzny) [The Oldest Naming Layer in Polish Lands (within the Limits of Early Medieval Slavdom)]. Kraków: Universitas.

Bijak, U., Czopek-Kopciuch, B. (2007). Imiona w nazwach jezior i stawów w Polsce [Personal Names in the Names of Polish Lakes and Ponds]. Jezikoslovni zapiski, 14, s. 59-82.

Bijak, U. (2013). Nazwy wodne dorzecza Wisły. Potamonimy odapelatywne [Hydronyms of the Vistula River Basin. Appellative-derived Potamonyms]. Kraków: IJP PAN.

Bilut, E. (1989). Klasyfikacja semantyczna nazw wodnych [Semantic Classification of Water Names]. W: K. Rymut (red.). Hydronimia słowiańska I. Materiały z IX konferencji Komisji Onomastyki Słowiańskiej przy Międzynarodowym Komitecie Slawistów, Mogilany, 16-18 IX 1986 r. [Slavonic Hydronymy I. Materials from the 9th Conference of the Slavic Onomastics Commission at the International Committee of Slavists, Mogilany, 16-18 September 1986] (s. 151-166). Wrocław-Warszawa: Ossolineum.

Bubak, J. (1970). Nazwiska ludności starostwa nowotarskiego. Część I [Names of the Population of the Nowy Targ Starostwo. Part I]. Wrocław-Warszawa-Kraków: Zakład Narodowy im. Ossolińskich.

Duma, J. (1999). Nazwy rzek lewobrzeżnego Mazowsza (z całym dorzeczem Pilicy) [River Names of the Left Bank of Mazovia (with the whole of the Pilica River Basin)].Warszawa: TWN.

ESHP - Elektroniczny słownik hydronimów Polski [Electronic Dictionary of Hydronyms in Poland], http://eshp.ijp.pan.pl.

Górnowicz, H. (1988). Synteza hydronimii dorzecza dolnej Wisły [Synthesis of the Hydronymy of the Basin of the Lower Vistula]. Gdańskie Studia Językoznawcze, IV, s. 29-41.

HE I — Górnowicz, H. (1985). Gewässernamen im Flußgebiet der unteren Weichsel (Nazwy wodne dorzecza dolnej Wisły). Stuttgart: Franz Steiner Verlag.

HE III - Rieger, J. (1988). Gewässernamen im Flußgebiet des Wisłok (Nazwy wodne dorzecza Wisłoka). Wiesbaden-Stuttgart: Franz Steiner Verlag.

HE IX — Rymut, K. (1993). Gewässernamen im Flußgebiet der oberen Weichsel von der Quelle bis zu Soła und Przemsza (Nazwy wodne dorzecza górnej Wisły od źródeł do Soły i Przemszy). Stuttgart: Franz Steiner Verlag.

HE VI — Mól, H. (1990). Gewässernamen im Flußgebiet des Wieprz (Hydronimia dorzecza Wieprza). Wiesbaden-Stuttgart: Franz Steiner Verlag.

HE X — Bilut, E. (1995). Gewässernamen im Flußgebiet des westlichen Bug (Nazwy wodne dorzecza Bugu). Stuttgart: Franz Steiner Verlag.

HE XII - Rymut, K. (1996). Rechte Zuflüsse zur Weichsel zwischen Soła und Dunajec (Nazwy wodne prawobrzeżnych dopływów Wisły między Sołą a Dunajcem). Stuttgart: Franz Steiner Verlag. 
HE XIII — Rymut, K., Majtán, M. (1998). Gewässernamen im Flußgebiet des Dunajec (Nazwy wodne dorzecza Dunajca). Stuttgart: Franz Steiner Verlag.

HE XIV — Duma, J. (1999). Gewässernamen im Linken Zuflußgebiet der Weichsel zwischen Pilica und Brda (Nazwy wodne w zlewisku lewych dopływów Wisły od Pilicy po ujście Brdy). Stuttgart: Franz Steiner Verlag.

HE XV — Rymut, K. (2000). Gewässernamen im rechten Zuflußgebiet der Weichsel zwischen Dunajec und Wisłok (Nazwy prawobrzeżnych dopływów Wisły między Dunajcem a Wisłokiem). Stuttgart: Franz Steiner Verlag.

HE XVI — Rymut, K. (2001). Gewässernamen im linken Zuflußgebiet der Weichsel zwischen Przemsza und Pilica (Nazwy lewobrzeżnych dopływów Wisły od Przemszy do Pilicy). Stuttgart: Franz Steiner Verlag.

HE XVII — Rieger, J. (2003). Gewässernamen im Flußgebiet des San, Teil I: Die fließenden Gewässer. A-O (Nazwy wodne dorzecza Sanu, I: Nazwy wód płynących. A-O). WiesbadenStuttgart: Franz Steiner Verlag.

HE XVIII — Rieger, J. (2004). Gewässernamen im Flußgebiet des San, Teil I: Die fließenden Gewässer. P-Ż; Teil II: Die stehenden Gewässer (Nazwy wodne dorzecza Sanu, I: Nazwy wód płynących. P-Ż; II: Nazwy wód stojących). Wiesbaden-Stuttgart: Franz Steiner Verlag.

HE XIX - Biolik, M. (2005). Gewässernamen im Flußgebiet der Narew von der Quelle bis zur Einmündung der Biebrza, Teil I: Die fließenden Gewässer (Nazwy wodne dorzecza Narwi od źródeł do ujścia Biebrzy, I: Nazwy wód płynących). Stuttgart: Franz Steiner Verlag.

Hladký, J. (2004). Hydronymia povodia Nitry [Hydronymy of the Nitra River Basin]. Trnava: Trnavská univerzita.

Krško, J. (2006). Antroponymá ako motivanty terénnych názvov a hydroným [Anthroponyms as Naming Motives of Feature Names and Hydronyms]. Acta onomastica, XLVII, s. 326-336.

Lubaś, W. (1963). Nazwy terenowe powiatów jasielskiego i krośnieńskiego [Place Names of the Jasło and Krosno Counties]. Onomastica, VIII, s. 195-236.

Łapicz, C. (1981). Terminologia geograficzna w ruskich gwarach Białostocczyzny na tle wschodniosłowiańskim [Geographical Terminology in the Russian Dialects of Białystok Region Against the East Slavonic Background]. Warszawa-Poznań-Torun: PWN.

Mól, H. (1996). Budowa słowotwórcza nazw wodnych dorzecza Wieprza [Word Formation of the Water Names in the Wieprz River Basin]. W: K. Rymut (red.). Hydronimia słowiańska II. Materiały z Międzynarodowej Konferencji Hydronimicznej, Mogilany, 20-24 września 1994 r. [Slavonic Hydronymy II. Materials from the International Hydronymic Conference, Mogilany, September 20-24, 1994] (s. 33-46). Kraków: Wyd. IJP PAN.

NMPol - Nazwy miejscowe Polski. Historia. Pochodzenie. Zmiany [Place Names of Poland. History. Origin. Changes]. T. I-XV. K. Rymut (red.) i inni. Kraków: IJP PAN, 1996-2018.

Rieger, J. (1969). Nazwy wodne dorzecza Sanu [Water Names in San River Basin]. Wrocław-Warszawa-Kraków: Zakład Narodowy im. Ossolińskich.

Rym SEN — Rymut, K. (1999-2001). Nazwiska Polaków. Słownik historyczno-etymologiczny [The Surnames of Poles. Historical-etymological Dictionary]. I: A-K, II: L-Ż. Kraków: IJP PAN.

Rymut, K. (1998). Nazwy wodne [Water Names]. W: E. Rzetelska-Feleszko (red.). Polskie nazwy własne. Encyklopedia [Polish Proper Names. Encyclopaedia] (s. 269-281). Warszawa-Kraków: TNW - IJP PAN.

Rzetelska-Feleszko, E. (1993). Nazwy geograficzne [Geographical Names]. W: Encyklopedia kultury polskiej XX wieku [Encyclopaedia of 20th Century Polish Culture]. T. 2: J. Bartmiński (red.): Współczesny język polski [Contemporary Polish Language] (s. 403-444). Wrocław: Wiedza o Kulturze.

Rzetelska-Feleszko, E., Duma, J. (1977). Nazwy rzeczne Pomorza między dolną Wisłą a dolną Odrą [River Names of Pomerania Between the Lower Vistula and the Lower Oder]. WrocławWarszawa-Kraków: Zakład Narodowy im. Ossolińskich - Wydawnictwo PAN. 
Snazw - Słownik nazwisk współcześnie w Polsce używanych [Dictionary of Surnames Currently Used in Poland]. Wyd. K. Rymut. T. I-X. Kraków: IJP PAN, 1992-1994.

Udolph, J. (1990). Die Stellung der Gewässernamen Polens innerhalb der alteuropäischen Hydronymie. Heidelberg: Carl Winter Universitätsverlag.

Wiśniewski, J. (1975). Dzieje osadnictwa w powiecie grajewskim do połowy XVI wieku [History of the Settlement in Grajewo County until the Mid-sixteenth Century. W: Studia i materiały do dziejów powiatu grajewskiego [Studies and Materials for the History of the Grajewo County]. I (s. 9-252). Warszawa.

Wolnicz-Pawłowska, E. (2013). O nazwach wodnych w Polsce [About Water Names in Poland]. Warszawa: DiG.

\title{
SUMMARY
}

\author{
DEANTHROPONYMIC POTAMONYMS IN THE VISTULA RIVER BASIN \\ (METHODOLOGICAL PROBLEMS AND TYPOLOGY OF NAMES)
}

\begin{abstract}
Water names, using the genetic-motivational criteria, can be divided into two superior groups: deappellative and deproprial hydronyms. Among the hydronyms derived from proper names, one can distinguish between the detoponymic and deanthroponymic. The names of flowing waters from anthroponyms are the subject of this article. Preliminary statistical data regarding deanthroponymic potamonyms in the Vistula river basin, their chronology, naming models, word formation bases and geographical distribution are presented. The results of the analysis show that the deanthroponymic potamonyms account for approximately $6.8 \%$ of the names of flowing waters of the Vistula river basin, estimated at more than 13,500. They appear sporadically in documents as early as in the 13th century, with only $12 \%$ visible until the 16 th century, with most of them not being noticed until the 19 th and 20th centuries. Such a statistical distribution is typical for the names of the flowing waters of that basin. Deanthroponymic names of rivers represent a variety of naming models, but most often appear as a part of compound names created with the suffix -ów, one-word formations with the same suffix and derivatives from the suf. $-k a$. They mainly identify objects located between the Sola River and the Dunajec River, especially in the Dunajec River basin, so in mountainous and submontainous areas, as K. Rymut claimed. The basis of such potamonyms are mainly personal names with different motivations, rarely being ethnonyms and first names.
\end{abstract}

Keywords: hydronomastics, river names, deanthroponymic derivatives, chronology, geography of names. 